\title{
An Empirical Study into the Impact of Entrepreneurial Failures on Subsequent Entrepreneurial Intention
}

\author{
LI Yingwen \\ School of Management \\ Zhejiang University \\ Hangzhou, China \\ liyingwen9999@126.com
}

\author{
DU Hong \\ School of Management \\ Zhejiang University \\ Hangzhou, China \\ duhong@zju.edu.cn
}

\begin{abstract}
As entrepreneurial activities are becoming more and more popular in China these years, considering the relative low success rate of entrepreneurship, it is of great importance that we study the influence of entrepreneurial failure on entrepreneurs' future entrepreneurial intentions and decisions. This article provides an empirical view of the relationship between entrepreneurial failures and subsequent entrepreneurial intention by studying into 159 Chinese entrepreneurs who have entrepreneurial failure experience before, and comes to a solid conclusion of the impacting relationship, hoping to provide researches a new perspective for future studies.
\end{abstract}

Keywords: entrepreneurial failures; emotional intelligence; subsequent entrepreneurial intention; entrepreneurial selfefficacy

\section{INTRODUCTION}

With the development of economy and technology, the topic of entrepreneurship is becoming more and more popular, while the study into entrepreneurial failures is still new and immature. Most studies of entrepreneurial failures nowadays are still focusing on the definition and causes of the failures. In terms of the relationship between entrepreneurial failures and subsequent entrepreneurial intention, there are a few former studies, but most of them are still using qualitative method and there are very few empirical studies about this topic.

In most cases, entrepreneurial failures would bring entrepreneurs great pain and trauma (Cope, 2011), and have negative effects on their confidence, self-efficacy and even tendency to risks (Shepherd, 2003). But we cannot deny that entrepreneurial failures could also be positive in that they can provide entrepreneurs with a great learning opportunity, helping them to rethink their entrepreneurial activities all along, enhance their entrepreneurial abilities and ensuring them a better performance the next time (McGrath, 1999). And some researches argue that failures are more motivating than successes, because failures can show the distance between dream and reality and push people to take more appropriate actions to achieve their goals (Staw \& Barsade, 1993).

Based on the above conflicts, this article first summarizes the study results on entrepreneurial failures both in China and abroad, then proposed a model on how the failures influence future entrepreneurial intention by studying into entrepreneurs who have failure experiences. After analyzing the first-hand data, it provides an empirical view on whether entrepreneurial failure experiences positively or negatively affect future entrepreneurial intention, and in which way do they influence future entrepreneurial intention.

\section{LITERATURE REVIEW}

\section{A. The Definition of Entrepreneurial Failure}

Currently, there are three main categories in the definition of entrepreneurial failure.

The first group is from the financial perspective. They think that once the company is liquidated or sold, then the entrepreneurs are regarded as having failed. Representing researches include Ulmer and Neilson (1947). Cochran (1981) expands the definition that as long as the company cannot exist any more, regardless whether entrepreneurs have lost money, the entrepreneurial activity is regarded as failure.

The second group defines entrepreneurial failure in the perspective of entrepreneurs' intention. It goes beyond the relatively narrow concept of the first group, such as bankruptcy and liquidation, and defines entrepreneurial failure as terminating companies that fail to accomplish short-term goals (McGrath, 1999; Politis \& Gabrielsson, 2009).

The definition of the third group is relatively wide. They think that as long as the result of the entrepreneurial activities haven't met what entrepreneurs have anticipated, the entrepreneurship is considered to be a failure (Cannon \& Edmondson, 2001; Politis \& Gabrielsson, 2009).

\section{B. The Concept of Entrepreneurial Self-Efficacy}

Albert Bandura (1977), a famous American psychologist, first raised the concept of self-efficacy during his research of social learning theory. Self-efficacy represents the level of confidence in accomplishing certain achievement based on one's personal skills. Entrepreneurial self-efficacy is gradually developed after self-efficacy was introduced into entrepreneurship research field. Boyd et al. (1994) defined it as "the intensity of individual belief in successfully acting as every entrepreneurial role and completing all entrepreneurial tasks". They regard it as one of the prerequisites of 
entrepreneurial behaviors. So we can define entrepreneurial self-efficacy as the entrepreneur's faith and confidence in entrepreneurial activities according to self-assessment.

\section{The Relationship Between Entrepreneurial Failures and Subsequent Entrepreneurial Intention}

Most of the studies on entrepreneurial failure experiences and subsequent entrepreneurial activities, especially entrepreneurial intentions, are qualitative studies. Very few empirical studies into this relationship exist.

From the mainstream researches, the relationship falls into two categories: positive impact and negative impact. Ucbasaran (2010) thinks that entrepreneurs who have failure experiences would learn more from the former entrepreneurial activities and would try harder in later entrepreneurship. Hayward (2010) studies into confident entrepreneurs, who tend to continue entrepreneurial activities even if they have failed. On the opposite, many researches claim that entrepreneurial failures would negatively affect entrepreneurs' intention to continue entrepreneurship. Cope (2011) claims that feeling of failure would quite possibly beat entrepreneurs' confidence and prevent them from starting a company again. In the meantime, if the financial loss of the failed company is high, the intention of subsequent entrepreneurship would be severely impaired.

\section{MODEL BUILDING AND HYPOTHESIS}

\section{A. Model Building}

As has been discussed in the literature review, researches hold very different opinions on whether entrepreneurial failure experience would have negative or positive influence on entrepreneurs' subsequent entrepreneurship. This study thinks that the difference occur because the former researches regard the failure experience as a whole rather than divide the experience into several dimensions to fully understand the influence. According to the literature review of different dimensions of entrepreneurial failure, this study divides entrepreneurial failure into three dimensions: severity of failure, anticipation of failure, and number of times of failure, to build a formative model for entrepreneurial failure.

Self-efficacy is the degree of confidence and faith one holds to accomplish certain entrepreneurial goals. While former researchers claim that failure experience affect subsequent entrepreneurial intention through affecting entrepreneurs' confidence (Hayward et al, 2010), opinions have differed on the influence of entrepreneurial failures on entrepreneurs' self-efficacy. Some researches argue that entrepreneurs with no failures before would have less retrospection of themselves and don't think they would possibly fail, which increases the chance of making errors, thus failure experience would push entrepreneurs to rethink themselves, learn from failures and enhance their selfefficacy. Others think the pain brought by failures would greatly beat entrepreneurs' confidence and reduce their selfefficacy. While it's generally acknowledged that high selfefficacy would enhance subsequent entrepreneurial intentions.
Moreover, researches have shown that emotional intelligence can also affect subsequent entrepreneurial intentions, in that entrepreneurs with high emotional intelligence can better control their sad negative feelings, motivate and encourage themselves, and more inclined to start entrepreneurship all over again.

Based on the relationship between entrepreneurial failure experience, emotional intelligence, entrepreneurs' selfefficacy and subsequent entrepreneurial intentions, this study proposes the following model on the influence of entrepreneurial failure on subsequent entrepreneurial intentions.

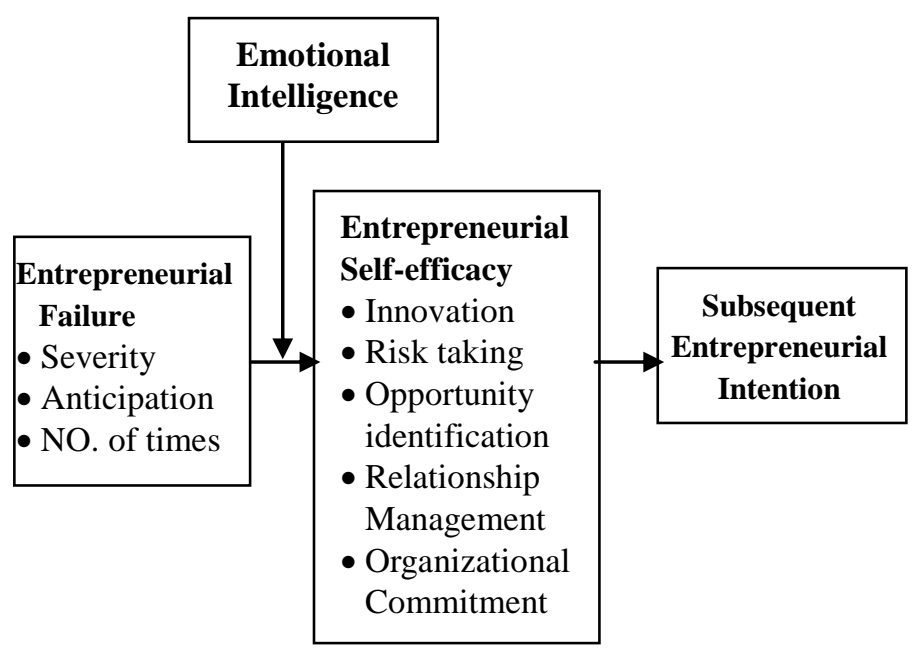

Chart 1. Model of the influence of entrepreneurial failure on subsequent entrepreneurial intention

\section{B. Hypothesis}

1) The influence of entrepreneurial failure on subsequent entrepreneurial intention

We divide entrepreneurial failure into three different dimensions: severity of failure, anticipation of failure, and number of times of failure.

Hypothesis 1a: The severity of failure is negatively correlated to subsequent entrepreneurial intention.

Hypothesis $1 b$ : The anticipation of failure is positively correlated to subsequent entrepreneurial intention.

Hypothesis 1c: Number of times of failure has a reversed U-shape relationship with subsequent entrepreneurial intention. With the increase of times of failure, subsequent entrepreneurial intention first increases and then decreases.

2) The mediating effect of entrepreneurial self-efficacy on the influence of entrepreneurial failure on subsequent entrepreneurial intention

Hypothesis 2a: Entrepreneurial self-efficacy has a mediating effect between the severity of failure and subsequent entrepreneurial intention.

Hypothesis 2b: Entrepreneurial self-efficacy has a mediating effect between anticipation of failure and subsequent entrepreneurial intention. 
Hypothesis 2c: Entrepreneurial self-efficacy has a mediating effect between number of times of failure and subsequent entrepreneurial intention.

3) The moderating effect of emotional intelligence on the influence of entrepreneurial failure on subsequent entrepreneurial intention

Hypothesis 3: Emotional Intelligence has a moderating effect between entrepreneurial failure and self-efficacy. The higher emotional intelligence, the more significant entrepreneurial failure influences entrepreneurial selfefficacy.

Hypothesis 3a: Emotional Intelligence has a moderating effect between severity of failure and self-efficacy.

Hypothesis $3 b$ : Emotional Intelligence has a moderating effect between anticipation of failure and self-efficacy.

\section{RESEARCh DESIGN AND DATA COLlection}

The questionnaire method is one of the main research methods in this study. The questionnaire used for this study has integrated many mature measuring standards and then the questionnaire is improved based on Chinese entrepreneurial environment.

Three main parts are included in the questionnaire: basic information including gender, age, education, etc.; information about entrepreneurship including entrepreneurial experience, industry and size of the company, whether they have entrepreneurial failure experience and the reasons and times for the failures; intellectual emotions, self-efficacy and subsequent entrepreneurial intention. WLEIS scale (Wong \& Law, 2004) is used to measure intellectual emotions; 7-point Likert scale is used to measure subsequent entrepreneurial intention and self-efficacy.

230 pieces of questionnaires are handed out to entrepreneurs and 196 pieces got back, in which we have 159 pieces of effective questionnaire results. All interviewees are entrepreneurs or former entrepreneurs in Zhejiang Province. And data from entrepreneurs who don't have entrepreneurial experience before are considered to be ineffective questionnaire results. Most interviewees are men, taking up $63.52 \%$, and most are between 26 to 35 years old.

\section{EMPIRICAL RESULTS}

\section{A. Correlation Analysis}

Pearson Correlation Coefficients are used in this correlation analysis. Detailed correlation data is shown in the following table.

TABLE I. Pearson Coefficient Result (N=159)

\begin{tabular}{|c|c|c|c|c|c|c|c|c|c|c|c|c|c|}
\hline & 1 & 2 & 3 & 4 & 5 & 6 & 7 & 8 & 9 & 10 & 11 & 12 & 13 \\
\hline 1.Severity of Failure & 1 & & & & & & & & & & & & \\
\hline 3.Times of Failure & .218 & -.064 & 1 & & & & & & & & & & \\
\hline 5.Innovation & -.117 & .099 & -.126 & $.428^{* *}$ & 1 & & & & & & & & \\
\hline 6.Risk Taking & .034 & .240 & -.132 & $.168^{*}$ & .017 & 1 & & & & & & & \\
\hline 7.Opportunity Identification & $-.232^{* *}$ & .036 & .017 & $.349^{* *}$ & $.593^{* *}$ & .089 & 1 & & & & & & \\
\hline 10.Emotional Intelligence & -.058 & .077 & -.150 & $.418^{*}$ & $.734^{*}$ & .038 & $.487^{* *}$ & $.600^{* *}$ & .581 & 1 & & & \\
\hline 11.Age & .022 & -.068 & -.058 & -.065 & -.064 & -.132 & $.181^{*}$ & -.008 & -.019 & .133 & 1 & & \\
\hline 12.Education & .093 & .040 & .101 & .016 & $.342^{* *}$ & -.084 & $.162^{*}$ & $.160^{*}$ & .248 & .290 & -.320 & 1 & \\
\hline 13.Gender & .041 & .079 & -.130 & -.149 & .000 & .095 & -.061 & .097 & -.030 & .012 & -.159 & -.021 & 1 \\
\hline
\end{tabular}

From the chart we can clearly see the correlation between two variables. Important results include:

- Severity and anticipation of failure are significant correlated with subsequent entrepreneurial intention, while times of failure don't prove to be quite correlated with subsequent entrepreneurial intention. The more severe the failure is, the less likely the entrepreneur is having subsequent entrepreneurship again. And the more anticipated about the failure, the more likely the entrepreneur will continue entrepreneurship.

- The severity of failure is significant negatively correlated with the five dimensions of self-efficacy. Anticipation of failure is significant positively correlated with self-efficacy and number of times of failure does not show to be correlated with selfefficacy.

- The five dimensions of self-efficacy are positively correlated with subsequent entrepreneurial intention, proving that higher self-efficacy will drive higher subsequent entrepreneurial intention.

- Emotional intelligence is not significantly correlated with entrepreneurial failure, including severity, anticipation and times, while it is significantly correlated with four dimensions of self-efficacy and subsequent entrepreneurial intention.

- Being control variables in this analysis, gender, age and education don't prove to be much correlated with other variables, except that education is highly positively correlated with self-efficacy. 


\section{B. Results Analysis of Regression Analysis and Hypothesis Testing}

1) The relationship between entrepreneurial failure and subsequent entrepreneurial intention

From Table II, we can see clearly that severity and anticipation of entrepreneurial failure both have significant impact on subsequent entrepreneurial intention, but in different ways and to different degrees.
The less severe the entrepreneurial failure is and the more anticipated about the failure itself, the higher subsequent entrepreneurial intention will be.

According to Table III, number of times of failure does not prove to have a reversed U-shape relationship with subsequent entrepreneurial intention. This probably occurs because most interviewees in this study have only failed once or twice, taking up $81 \%$ of total interviewees, reaching a different result.

TABLE II. REGRESSION ANALYSI TABLE FOR THE INFLUENCE OF SEVERITY AND ANTICIPATION OF FAILURE ON SUBSEQUENT ENTREPRENEURIAL INTENTION

\begin{tabular}{|c|c|c|c|c|c|c|c|c|c|c|c|c|c|c|}
\hline \multirow{2}{*}{ Variable } & \multicolumn{2}{|c|}{ Model 1} & \multicolumn{2}{|c|}{ Model 2} & \multicolumn{2}{|c|}{ Model 3} & \multicolumn{2}{|c|}{ Model 4} & \multicolumn{2}{|c|}{ Model 5} & \multicolumn{2}{|c|}{ Model 6} & \multicolumn{2}{|c|}{ Model 7} \\
\hline & $\beta$ & Sig. & $\beta$ & Sig. & $\beta$ & Sig. & $\beta$ & Sig. & $\beta$ & Sig. & $\beta$ & Sig. & $\beta$ & Sig. \\
\hline Gender & $-.165 *$ & .042 & $-.163^{*}$ & .035 & $-.170^{*}$ & .015 & $-.170 *$ & .027 & $-.161^{*}$ & .028 & $-.200 * *$ & .007 & $-.160 *$ & .027 \\
\hline Age & -.098 & .251 & -.070 & .385 & -.100 & .175 & -.046 & .573 & $-.162 *$ & .043 & -.095 & .217 & -.098 & .196 \\
\hline Education & -.019 & .821 & .009 & .914 & $-.155^{*}$ & .047 & .032 & 690 & -.082 & .299 & -.054 & .481 & -.093 & .236 \\
\hline Failure Severity & & & $-.277 * *$ & .000 & $-.210 * *$ & .003 & $-.285^{* *}$ & .000 & $-.190 *$ & .012 & $-.245 * *$ & .001 & $-.208 * *$ & .005 \\
\hline $\begin{array}{c}\text { Failure } \\
\text { Anticipation }\end{array}$ & & & $.176^{*}$ & .021 & $.140 *$ & .043 & .140 & .071 & $.163 *$ & .024 & $.174 *$ & .016 & $.157^{*}$ & .028 \\
\hline Innovation & & & & & $.436 * *$ & .000 & & & & & & & & \\
\hline Risk taking & & & & & & & $.157 *$ & .046 & & & & & & \\
\hline $\begin{array}{l}\text { Opportunity } \\
\text { Recognition }\end{array}$ & & & & & & & & & $.332 * *$ & .000 & & & & \\
\hline $\begin{array}{l}\text { Relationship } \\
\text { Management }\end{array}$ & & & & & & & & & & & $.322 * *$ & .000 & & \\
\hline $\begin{array}{l}\text { Organization } \\
\text { Commitment }\end{array}$ & & & & & & & & & & & & & $.350 * *$ & .000 \\
\hline $\mathrm{R}^{2}$ & & & .12 & & .31 & & .16 & & .2 & & .2 & & .24 & \\
\hline$\Delta \mathrm{R}^{2}$ & & & .10 & & .10 & & .02 & & .0 & & .0 & & .10 & \\
\hline $\mathrm{F}$ & & & 4.97 & & 10.9 & & 4.89 & & 7.67 & & 7.93 & & 8.40 & \\
\hline
\end{tabular}

$* \mathrm{p}<0.05 ; * * \mathrm{p}<0.01$

TABLE III. REGRESSION ANALYSI TABLE FOR THE NUMBER OF TIMES OF FAILURE ON SUBSEQUENT ENTREPRENEURIAL INTENTION

\begin{tabular}{cccccc}
\hline Variable & $\beta$ & $\mathrm{R}^{2}$ & adj. $\mathrm{R}^{2}$ & $\mathrm{~F}$ & Sig. \\
\hline $\begin{array}{c}\text { Number of } \\
\text { Times }\end{array}$ & -.191 & & & & \\
$\begin{array}{c}\text { Number of } \\
\text { Times }\end{array}$ & .167 & .003 & -.010 & .238 & .788 \\
\hline
\end{tabular}

2) The mediating effect of entrepreneurial self-efficacy

From Table II, we can see that self-efficacy acts as partial mediation in the relationship between severity of failure and subsequent entrepreneurial intention, and the relationship between anticipation of failure and subsequent entrepreneurial intention. This means that severity and anticipation of failure can not only directly affect subsequent entrepreneurial intention, but also affect subsequent entrepreneurial intention through affecting self-efficacy.

Anticipation of failure affect subsequent entrepreneurial intention through risk taking self-efficacy (complete mediation), innovation self-efficacy (partial mediation), opportunity recognition (partial mediation), relationship management self-efficacy (partial mediation), and organization commitment self-efficacy (partial mediation).

Severity of failure affects subsequent entrepreneurial intention through innovation self-efficacy (partial mediation), opportunity recognition (partial mediation), and organization commitment self-efficacy (partial mediation).
From the above analysis, we can see the five dimensions of entrepreneurial self-efficacy have both complete mediation effect and partial mediation effect between severity and anticipation of failure and subsequent entrepreneurial intention.

3) Moderating effect of emotional intelligence

Variance analysis is used in measuring the moderating effect of emotional intelligence.

TABLE IV. THE MODERATING EFFECT OF EMOTIONAL INTELLIGENCE ON SEVERITY OF FAILURE AND SUBSEQUENT ENTREPRENEURIAL INTENTION ( $\mathrm{N}=159)$

\begin{tabular}{ccc}
\hline Factor & F & Significance \\
\hline $\begin{array}{c}\text { Emotional } \\
\text { Intelligence*Failure } \\
\text { Severity }\end{array}$ & .870 & .421 \\
\hline
\end{tabular}

TABLE V.THE MODERATING EFFECT OF EMOTIONAL INTELLIGENCE ON SEVERITY OF FAILURE AND SUBSEQUENT ENTREPRENEURIAL INTENTION $(\mathrm{N}=159)$

\begin{tabular}{ccc}
\hline Factor & $\mathrm{F}$ & Significance \\
\hline Emotional & & \\
Intelligence*Failure & $11.875^{* *}$ & .000 \\
Anticipation & & \\
$<0.05, * * \mathrm{p}<0.1$ & &
\end{tabular}

Emotional intelligence does not have a moderating effect on the relationship between severity of failure and subsequent entrepreneurial intention. 
Emotional intelligence has a moderating effect on the relationship between anticipation of failure and subsequent entrepreneurial intention. The higher emotional intelligence is, the more significant the relationship will be.

\section{SUMMARY}

\section{A. Practical Insights}

- As the study shows that the more severe the failure is, the less likely the entrepreneur is willing to start a business again. In cases of signs of failure, including significant profit losing and incresing cost, entrepreneurs should rethink whether this is still a good business to go, and quit before the loss goes beyond one can handle, reducing the severity of the failure in time.

- Entrepreneurs should be more observant of the market and the company itself, and should not be too optimistic of the results of the entrepreneurship. Little anticipation of failure would greatly increase the harm to the entrepreneur after a failure, which decrease their subsequent entrepreneurial intention.

- Friends and family should pay more attention to entrepreneurs who have failure experiences before, encourage and help them to alleviate the pain. As is shown in the study, self-efficacy greatly affects one's entrepreneurial intention, thus building up self-efficacy after failure is very important.

- Emotions should be properly controlled if there is a failure. Entrepreneurs should be more optimistic about the failure itself, learn from the failure and get themselves better prepared for future entrepreneurship, rather than get over pessimistic and unconfident about themselves.

\section{B. Limits to the study}

1) Authenticity of interviewees' answers to the questionnaire

Since the interviewees in this study are entrepreneurs who have failure experience before, considering some entrepreneurs are not willing to admit or talk about their failures, there might be some bias in the questionnaire results.

2) Dimensions of entrepreneurial failure may not be overall inclusive

Entrepreneurial failure is a relatively broad concept. This study tries to divide entrepreneurial failure into several dimensions, while this division may not be the best division and might have ignored some other dimensions.

3) Time to the failure might influence interviewees' answers

Time duration matters a lot to entrepreneurial failure and subsequent entrepreneurial intention. Normally, the longer the failure has past, the more positive attitude towards the failure and entrepreneurs themselves, and the higher their subsequent entrepreneurial intention. While due to the limitation of measurement, time span is not considered in this study.

\section{Future research prospects}

1) Establish a follow-up study to have a more accurate data.

Since most financial results are not open to the pubic, it is hard to do financial analysis along the way. Besides, entrepreneurs might not want to talk about their failure experience. Future study can have a longer time span on entrepreneurial failure, which can generate results from different time period of the failure, which would be more objective.

\section{2) Study of the influence of entrepreneurial} experience on entrepreneurial intention

Subsequent entrepreneurial intention is based on the fact that entrepreneurs have entrepreneurial experience before. Whether entrepreneurial intention would be affected by entrepreneurial experience is a topic needs studying.

3) Study of the measurement of entrepreneurial failure

As the study in entrepreneurial failure arouses more and more attention from researches, a more accurate division of entrepreneurial failure into different dimensions could be studied to better serves the needs for entrepreneurial study in the future.

\section{ACKNOWLEDGMENT}

The authors thank all of the anonymous interviewees in the study for their time. The authors acknowledge that the design of the questionnaire and the paper has benefited from valuable suggestions and comments of several interviewees.

\section{REFERENCES}

[1] Beaver, G., \& Jennings, P. L. The abuse of entrepreneurial power-an explanation of management failure. Strategic Change, 1996, 5(3): 151-164.

[2] Bird, B. J. \& Brush, C. G. A gendered perspective on organizational creation. Entrepreneurship Theory and Practice, 2003, 26(3): 41-65.

[3] Boyd, N., \& Vozikis, G. S. The influence of self-efficacy on the development of entrepreneurial intentions and actions. Entrepreneurship Theory and Practice, 1994, 18(1): 63-77.

[4] Brewer, M. B. \& Hewstone, M. Social Cognition: Perspectives on Social Psychology, 2003, Blackwell, Oxford.

[5] Cannon, M. D., \& Edmondson, A. C. Confronting failure: antecedents and consequences of shared belief about failure in organizational work groups. Journal of Organizational Behavior, 2001, 22: 161-77.

[6] Cardon, M. S., Stevens, C. E., \& Potter, D. R. Misfortunes or mistakes? Cultural sensemaking of entrepreneurial failure. Journal of Business Venturing, 2011, 26: 79-92.

[7] Carter, S., \& Wilton, W. Don't blame the entrepreneur, blame the government: the centrality of the government in enterprise development: lessons from enterprise failure in Zimbabwe. Journal of Enterprising Culture, 2006, 14: 65-84.

[8] Chen, C. C., Greene, P. G., \& Crick, A. Does entrepreneurial selfefficacy distinguish entrepreneurs from managers? Journal of Business Venturing, 1998, 13: 295-316.

[9] Clute, R. C., \& Garman, G. B. The effect of U.S economic policies on the rate of business failure. American Journal of Small Business, 1980, 5(1): 6-12.

[10] Cope, J. Entrepreneurial learning and critical reflection: discontinuous events as triggers for 'higher-level' learning, Management Learning, 2003, 34(4): 29-50. 
[11] Cope, J. Entrepreneurial learning from failure: An interpretative phenomenological analysis. Journal of Business Venturing, 2011, 26: 604-623.

[12] Cope, J., Cave, F., \& Eccles, S. Attitudes of venture capital investors towards founders with previous business failure. Venture Capital, 2004, 6(2/3): 147-173.

[13] De Noble, A. F., Jung, D., \& Ehrlich, S. Entrepreneurial self-efficacy: the development of a measure and its relationship to entrepreneurial action. Frontiers of Entrepreneurship Research. Babson College, Wellesley, MA, 1999.

[14] Drnovsek, M. \& Erikson, T. Competing models of entrepreneurial intentions. Economic and Business Review for Centraland SouthEastern Europe, 2005, 7(1): 55-71.

[15] Gupta, A. Is failure so bad? Mid-American Journal of Business, 2005, 20(1): 3-4.

[16] Hayward, M. L. A., Forster, W. R., Sarasvathy, S. D., \& Fredrickson, B. L. Beyond hubris: How highly confident entrepreneurs rebound to venture again. Journal of Business Venturing, 2010, 25: 569-578.

[17] Hayward, M. L. A., Shepherd, D.A., \& Griffin, D. A hubris theory of entrepreneurship. Management Science, 2006, 52: 160-172.

[18] Headd, B. Redefining business success: distinguishing between closure and failure. Small Business Economics, 2003, 23(1): 51-61.

[19] Kazanjian, R. K. Relation of dominant problems to stage of growth in technology based new ventures. Academy of Management Journal, 1988, 31(2): 257-279.

[20] Kolb, D. A., Boyatzis, R. E. \& Mainemelis, C. Experiential learning theory: previous research and new directions, in Sternberg, R.J. and Zhang, L.F. (Eds), Perspectives on Cognitive, Learning, and Thinking Styles, Lawrence Erlbaum, Mahwah, NJ, 2001, 227-47.

[21] Krueger, N., Reilly, M., \& Carsrud, A. Competing models of entrepreneurial intentions. Journal of Business Venturing, 2000, 15(5): 411-432.

[22] McGrath, R.G. Falling forward: real options reasoning and entrepreneurial failure. Academy of Management Journal, 1999, 24: 13-30.

[23] Meyer, G. D., \& Dean, T. J.,An upper echelons perspective on transformational leadership problems in high technology firms. The
Journal of High Technology Management Research, 1990, 1(2): 223 242.

[24] Politis, D., \& Gabrielsson, J. Entrepreneurs' attitudes towards failure: an experiential learning approach. International Journal of Entrepreneurial Behaviour and Research, 2009, 5(4): 364-383.

[25] Sarasvathy, S., \& Menon, A. Failingfirms and successful entrepreneurs: serial entrepreneurship as a temporal portfolio. Darden Business School Working Paper, 2002: 4-5.

[26] Sequeira, J. The influence of social ties and self-efficacy in forming entrepreneurial intentions and motivating nascent behaviour. Journal of Developmental Entrepreneurship, 2007 , 12(2): 275-293.

[27] Shepherd, D. A. Learning from business failure: propositions about the grief recovery process for the self-employed. Academy of Management Review, 2003, 28: 318-29.

[28] Shepherd, D. A., Douglas, E. J., \& Shanley, M. New venture survival: ignorance, external shocks, and risk reduction strategies. Journal of Busi ness Venturing, 2000, 15: 393-410.

[29] Souitaris, V., Zerbinati, S., \& Al-Laham, A. Do entrepreneurship programmes raise entrepreneurial intention of science and engineering students? The effect of learning, inspiration and resources. Journal of Business Venturing, 2007, 22: 566-591

[30] Staw, B.M., \& Barsade, S.G. Affect and managerial performance: a test of the sadder-but-wider versus happier-and-smarter hypotheses. Administrative Science Quarterly, 1993, 38: 304-331.

[31] Ucbasaran, D., Westhead, P., Wright, M., \& Flores, M. The nature of entrepreneurial experience, business failure and comparative optimism. Journal of Business Venturing, 2010, 25: 541-555.

[32] Van Gelderen, M., van de Sluis, L. \& Jensen, P. Learning opportunities and learning behaviours of small business starters: relations with goal achievement, skill development and satisfaction, Small Business Economics , 2005, 25: 97-108.

[33] Weisenfeld, B.M., Wurthmann, K.A., \& Hambrick, D.C. The stigmatization and devaluation of elites associated with corporate failures: a process model. Academy of Management Review, 2008, 33: $231-251$.

[34] Wood, R., \& Bandura, A. Social cognitive theory of organizational management. Academy of Management Review, 1989, 14: 361-384. 